\title{
- PIELĘGNIARSTWO - ZAWÓD SZCZEGÓLNIE NARAŻONY NA WYPALENIE ZAWODOWE - CZĘŚĆ II. DONIESIENIE Z BADAN'*
}

\section{NURSING AS A PROFESSION PARTICULARLY EXPOSED TO PROFESSIONAL BURNOUT - PART II. RESEARCH REPORT *}

\author{
Iwona Nowakowska', Katarzyna Roszak², Renata Rasińska', Agnieszka Bańkowska ${ }^{3}$ \\ ${ }^{1}$ Zakład Organizacji i Zarządzania w Opiece Zdrowotnej \\ Uniwersytet Medyczny im. Karola Marcinkowskiego w Poznaniu \\ ${ }^{2}$ Wydział Nauk o Zdrowiu \\ Uniwersytet Medyczny im. Karola Marcinkowskiego w Poznaniu \\ ${ }^{3}$ Zakład Higieny i Epidemiologii \\ Collegium Medicum w Bydgoszczy UMK w Toruniu
}

DOI: https://doi.org/10.20883/pielpol.2017.30

\section{STRESZCZENIE}

Cel. Analiza występowania wypalenia związanego z pracą oraz w kontaktach z pacjentami wśród pielęgniarek zatrudnionych w podmiotach leczniczych.

Materiał i metody. W badaniu wzięło udział 111 pielęgniarek zatrudnionych w poznańskim szpitalu. Wyniki zgromadzono na podstawie wypełnionych kwestionariuszy ankiety Copenhagen Burnout Inventory. Analizie poddano dwa z trzech obszarów wyodrębnionych w CBI: wypalenie związane z pracą oraz wypalenie w kontaktach z pacjentami.

Wyniki. Badane pielęgniarki narażone są na wypalenie związane z pracą, w mniejszym stopniu na wypalenie związane z pacjentami. Najwięcej respondentek odczuwa objawy wyczerpania fizycznego oraz zmęczenia, a także wyczerpania emocjonalnego. Znaczna większość badanych pielęgniarek zdaje sobie sprawę, że praca z pacjentami jest trudna, niezależnie od wieku czy stażu pracy, jednak nie odczuwają jej jako frustrującej. Wypalenie zawodowe nie pozostaje bez wpływu na rodzinę respondentek. Co czwarta badana pielęgniarka nie ma wystarczającej ilości czasu dla bliskich.

Wnioski. W przeprowadzonym badaniu posiadane wykształcenie oraz oddział, na jakim pracuje pielęgniarka, w znacznym stopniu wpływają na występowanie symptomów wypalenia zawodowego. Wypalenie zawodowe związane z pracą negatywnie wpływa na wykonywanie obowiązków oraz na relacje z rodziną. Większość badanych pielęgniarek ma świadomość, że ich praca jest trudna, jednak nie wpływa to na relacje z pacjentami.

SŁOWA KLUCZOWE: pielęgniarki, wypalenie związane z pracą, wypalenie w kontaktach z pacjentami.

\section{Wstęp}

Zdaniem duńskiego profesora Kristensena i jego współpracowników wypalenie zawodowe można definiować z punktu widzenia obszarów, których dotyczy, a których przeważającymi objawami zdają się być te o wymia-

\begin{abstract}
Aim. Analysis of the incidence of burnout associated with work and in patient contacts among nurses employed in healthcare entities.

Material and methods. 111 nurses employed in the Poznań hospital participated in the study. The results are based on completed Copenhagen Burnout Inventory questionnaires. Two of the three areas identified in the CBI were analyzed: burnout associated with work and burnout connected with patients.

Results. The examined nurses are exposed to burnout associated with work, and, to a lesser extent, to burnout associated with patients. The majority of respondents experience symptoms of physical exhaustion and fatigue, as well as emotional exhaustion. The vast majority of surveyed nurses are aware that working with patients is difficult, regardless of age or length of service, but they do not feel frustrated. Professional burnout does not affect the respondents' families. Every fourth researched nurse does not have enough time for loved ones.

Conclusions. In the study conducted, the occupational education and affiliation of the nurse significantly influenced the incidence of burnout. Work-related burnout negatively affects the performance of your duties and relationships with your family. Most of the surveyed nurses are aware that their work is difficult, but it does not affect the relationship with patients.
\end{abstract}

KEYWORDS: nurse, burnout associated with work, burnout connected with patients. 
z pracą - charakteryzujące się „fizycznym i psychicznym zmęczeniem czy wyczerpaniem odczuwanym przez osobę podczas wykonywania pracy" oraz wypalenie w kontaktach z klientami, będące „fizycznym i psychicznym zmęczeniem czy wyczerpaniem odczuwanym przez daną osobę przy kontaktach z klientami" [1, 2].

\section{Cel}

Celem opracowania jest analiza występowania wypalenia związanego z pracą oraz w kontaktach z pacjentami wśród pielęgniarek zatrudnionych w oddziałach szpitalnych w podmiotach leczniczych.

\section{Materiał i metody}

Badanie kwestionariuszowe przeprowadzono z udziałem 111 pielęgniarek zatrudnionych w jednym z poznańskich szpitali. Wyniki zgromadzono na podstawie wypełnionych kwestionariuszy ankiety Copenhagen Burnout Inventory. Analizie poddano dwa z trzech obszarów wyodrębnionych w CBI: wypalenie związane z pracą oraz wypalenie w kontaktach z pacjentami.

Najwięcej pielęgniarek, spośród biorących udział w badaniu, znajduje się w przedziałach wiekowych: do 25 lat i $26-30$ lat (w sumie $31 \%$ ) oraz po 46 roku życia, (także $31 \%$ badanych). Najmniej respondentek znajduje się w grupie 36-40 lat - 7\% oraz 31-35 lat $9 \%$. Poziom wykształcenia zatrudnionych pielęgniarek rozkłada się równomiernie: $53 \%$ zatrudnionych posiada wykształcenie wyższe, 47\% wykształcenie średnie medyczne. Dużą różnicę zaobserwować można w ilości pielęgniarek pracujących w systemie zmianowym: $81 \%$ badanych pracuje $\mathrm{w}$ systemie zmianowym, 19\% nie pracuje w systemie zmianowym.

\section{Wyniki}

\section{Wypalenie związane z pracą}

Najmniejszą liczbę symptomów wypalenia związanego z pracą odczuwają pielęgniarki w wieku do 25 lat (33\% w małym stopniu, $61 \%$ w bardzo małym stopniu) oraz w wieku 36-40 lat (63\% w małym stopniu, 13\% w bardzo małym stopniu). Najczęściej natomiast doświadczają ich kobiety w wieku 41-45 lat (38\% w dużym stopniu, $8 \%$ w bardzo dużym stopniu). W kolejnych przedziałach wiekowych odczuwanie objawów wypalenia z powodu wykonywanej pracy spada.

Zwrócono uwagę, że pielęgniarki z wykształceniem wyższym w mniejszym stopniu odczuwają objawy wypalenia z powodu wykonywanej pracy, rzadziej każdą godzinę pracy odbierają jako męczącą oraz mają więcej czasu dla rodziny i przyjaciół, natomiast odczuwanie pracy jako wyczerpującej emocjonalnie jest porównywalne dla obydwu grup. Pracę jako wyczerpującą emocjonalnie postrzega w stopniu bardzo dużym i dużym 64\% pielęgniarek z wykształceniem średnim medycznym (w bardzo dużym stopniu 35\%, w dużym stopniu 29\%) oraz 66\% z wykształceniem wyższym (w bardzo dużym stopniu 15\%, w dużym stopniu 51\%). Nieznaczną różnicę można zaobserwować przy postrzeganiu pracy jako wyczerpującej emocjonalnie (odpowiedź: trochę) - 29\% pielęgniarki z wykształceniem średnim medycznym, 22\% z wyższym. Co czwarta pielęgniarka z wykształceniem średnim czuje, że każda godzina pracy jest męcząca zawsze i często, wśród pielęgniarek z wykształceniem wyższym żadna z pielęgniarek nie wskazała tej odpowiedzi. Czasami każda godzina pracy jest męcząca dla $40 \%$ pielęgniarek z wykształceniem średnim medycznym oraz $36 \%$ z wykształceniem wyższym. Wystarczającą ilość energii dla rodziny i przyjaciół w wolnym czasie posiada zawsze 13\% pielęgniarek z wykształceniem średnim i 14\% z wykształceniem wyższym, często ma czas $21 \%$ respondentek $z$ wykształceniem średnim medycznym i prawie dwukrotnie więcej badanych z wyższym wykształceniem - $41 \%$.

Pielęgniarkami, które najrzadziej odczuwają, że ich praca jest wyczerpująca emocjonalnie, są te, których staż pracy jest najkrótszy oraz najdłuższy.

Pielęgniarki ze wszystkich oddziałów w większości uważają, że ich praca jest wyczerpująca emocjonalnie w dużym i bardzo dużym stopniu.

\section{Wypalenie w kontaktach z pacjentami}

Pielęgniarki z wykształceniem średnim w większym stopniu odczuwają symptomy wypalenia w kontaktach z pacjentami.

35\% badanych pielęgniarek z wykształceniem średnim i 12\% z wyższym zastanawia się, jak długo będzie w stanie kontynuować pracę z pacjentami.

Pielęgniarki z najkrótszym stażem pracy są najrzadziej zmęczone pracą z pacjentami (rzadko 48\%, nigdy/ prawie nigdy 15\%) natomiast najczęściej zmęczenie pracą z pacjentami odczuwają osoby ze stażem pracy 6-10 lat (6\% zawsze, 35\% często) oraz 21-25 lat (36\% często).

Największa liczba pielęgniarek, które zastanawiają się, jak długo będą w stanie kontynuować pracę z pacjentami, zatrudniona jest na Oddziale Urologii i Onkologii Urologicznej (60\% często) oraz na Oddziale Chorób Wewnętrznych i Kardiologii z Pododdziałem Diagnostyki Kardiologicznej (20\% zawsze, 40\% często). Najrzadziej nad możliwością kontynuacji pracy z pacjentem zastanawiają się pielęgniarki zatrudnione w Klinice Neurologii i Chorób Naczyniowych Układu Nerwowego z Pododdziałem Leczenia Udarów (39\% rzadko, 22\% nigdy/prawie nigdy), na Oddziale Anestezjologii i Intensywnej Terapii (25\% rzadko, 31\% nigdy/ 
prawie nigdy) oraz w Izbie Przyjęć (30\% rzadko, 20\% nigdy/prawie nigdy).

\section{Dyskusja}

Badanie Kristensena i wsp. wykazało, że pielęgniarki częściej narażone są na wypalenie związane z pracą niż na wypalenie związane z pacjentami [1]. Wyniki te zostały potwierdzone w badaniu przeprowadzonym wśród 819 japońskich pielęgniarek w szpitalu uniwersyteckim w Tokio przez M. Shimizutani i wsp. [3]. Maslach i Jackson w swoim badaniu uzyskały specyficzny obraz wypalenia zawodowego. Wraz ze wzrostem ilości obowiązków przypadających na jedną pielęgniarkę oraz ze spadkiem możliwości podejmowania decyzji wzrasta wyczerpanie emocjonalne [4].

W niniejszym badaniu zwrócono uwagę na związek pomiędzy wybranymi danymi socjodemograficznymi a ewentualnym odczuwaniem symptomów wystąpienia wypalenia. Pielęgniarki posiadające wykształcenie średnie medyczne są narażone na wystąpienie wypalenia zawodowego w większym stopniu niż pielęgniarki posiadające wykształcenie wyższe, co zostało potwierdzone w artykule naukowym autorstwa Maslach i wsp. [5] oraz w polskim badaniu Nowak-Starz i wsp. [6].

Rodzaj i specyfika oddziału mają wpływ na występowanie wypalenia zawodowego wśród pielęgniarek. Najbardziej narażone są pielęgniarki pediatryczne, onkologiczne oraz pracujące z pacjentami chorymi psychicznie. Teza ta została częściowo potwierdzona w niniejszym badaniu. Codzienna praca z nieuleczalnie chorymi pacjentami, próba pomocy, która często kończy się niepowodzeniem, świadomość, że nie jest się w stanie pomóc choremu, powodują, że pielęgniarki pracujące na oddziałach onkologicznych są narażone w największym stopniu na występowanie wypalenia zawodowego [4].

Z przeprowadzonego badania własnego wynika, że ponad połowa respondentek jest zawsze lub często zmęczona, natomiast wyczerpanych fizycznie jest $42 \%$ badanych. W analizie Lewandowskiej i Litwin wśród objawów wymienia się: zmęczenie, wyczerpanie, bóle kręgosłupa, bóle i zawroty głowy, bóle serca, zaburzenia żołądkowo-jelitowe [7]. W badaniu Nowak-Starz i wsp. wykazano istotny statystycznie związek pomiędzy odczuwaniem zmęczenia przez pielęgniarki a występowaniem wypalenia zawodowego [6].

Stresogenne sytuacje w pracy zawodowej wpływają także na życie osobiste i rodzinne pielęgniarek. Najczęściej jest to obniżenie zainteresowania sprawami rodzinnymi, nieporozumienia, konflikty oraz brak czasu [7]. Wśród fizycznych czynników zwiększających ryzyko wypalenia związanego z pracą wymienia się m.in.: brak możliwości odpoczynku w ciągu dnia pracy oraz brak dni wolnych od pracy, które można by wykorzystać na podnoszenie kwalifikacji [8].

W badaniu Dłużewskiej pielęgniarki wskazały najbardziej komfortowe elementy swojej pracy. Wymieniły m.in.: kontakt z chorymi, podawanie iniekcji, zmienianie opatrunków, udział w wizytach lekarskich. Po przeciwnej stronie sklasyfikowały: rozbudowane czynności dokumentacyjne, prace przy komputerze, podnoszenie pacjentów, sprzątanie [9]. Dla 70\% pielęgniarek biorących udział w badaniu praca z pacjentem jest trudna. Sytuacja ta może być spowodowana również tym, że w swojej pracy doświadczają agresji słownej czy sytuacji konfliktowych, najczęściej ze strony pacjentów oraz rodziny chorego [7, 9].

Zjawisko wypalenia zawodowego analizowane oraz badane jest przez wielu naukowców od lat 70 . XX wie$\mathrm{ku}$. W wieloletniej pracy wyodrębnili oni metody badań tego zjawiska oraz wskazali na zależności, które mogą wpływać na wypalenie zawodowe. Ilość przeprowadzonych badań i opracowanych artykułów naukowych powinna zwrócić uwagę zespołów kierowniczych oraz samych pracowników na to, że warto a nawet należy stosować mechanizmy obronne przeciwdziałające pojawieniu się symptomów wypalenia zawodowego, ponieważ jego negatywne konsekwencje są odczuwane wielopłaszczyznowo przez pracowników i ich rodziny, pacjentów, organizację oraz społeczeństwo.

\section{Wnioski}

Na podstawie wyników otrzymanych z przeprowadzonego badania, sformułowano następujące wnioski:

1. Wśród badanych pielęgniarek występują symptomy wypalenia. Posiadane wykształcenie oraz oddział, na jakim zatrudnione są pielęgniarki, wpływają na występowanie objawów wypalenia.

2. Wypalenie zawodowe związane z pracą może niekorzystnie wpływać na wykonywanie obowiązków zawodowych oraz na relacje z rodziną.

3. Większość badanych pielęgniarek ma świadomość, że ich praca jest trudna, jednak nie wpływa to na relacje z pacjentami.

4. Pielęgniarki częściej odczuwają symptomy wypalenia związanego z pracą aniżeli wypalenia związanego z pacjentem.

\section{Piśmiennictwo}

1. Kristensen TS, Borritz M, Villadsen E. i wsp. The Copenhagen Burnout Inventory: A New Tool for the Assessment of Burnout. Work \& Stress 2005; 19(3): 192-207.

2. Kristensen TS, Borritz M. Copenhagen Burnout Inventory: Normative Data from a Representative Danish Population on Personal Burnout, Work Burnout and Client Burnout. National Institute of Occupational Health, Copenhagen 2001, Denmark. 
3. Shimizutani M, Odagiri Y, Ohya Y, Shimomitsu T, Kristensen TS, Maruta T, Ilmori M. Relationship of Nurse Burnout with Personality Characteristics and Coping Behaviors. Ind Health 2008; 46: 322.

4. Beisert M. Przejawy, mechanizmy i przyczyny wypalania się pielęgniarek. Sęk H. (red.), Wypalenie zawodowe. Przyczyny. Mechanizmy. Zapobieganie. Warszawa: PWN; 2009.

5. Maslach Ch, Schaufeli WB, Leiter MP, Job Burnout, Annu Rev Psychol 2001; 52: 397-422.

6. Nowak-Starz G, Kozak B, Zdziebło K. Wpływ stresu związanego z pracą zawodową na występowanie zespołu wypalenia zawodowego u pielęgniarek pracujących na oddziałach zabiegowych i zachowawczych, Stud Med 2013; 29(1): 15-21.

7. Lewandowska A, Litwin B. Wypalenie zawodowe jako zagrożenie w pracy pielęgniarki, Rocz PAM, 2009; 55/3: 86-89.

8. Kilańska D, Gorzkowicz B, Sienkiewicz Z, Lewandowska M, Dominiak I, Bielecki W. Evaluation of chosen determinants of the positive preactice environments (PPE) at Polish Nursing Wards. Med Pr 2016; 67(1): 11-19.

9. Dłużewska M. Eksploracja uwarunkowań w powstaniu procesu wypalenia zawodowego - analiza na podstawie badań własnych, Piel Pol 2012; 2(44): 63-72.
*Artykuł zawiera obszerne fragmenty pracy magisterskiej, realizowanej przez lic. Katarzynę Roszak na Wydziale Nauk o Zdrowiu, w Zakładzie Organizacji i Zarządzania w Opiece Zdrowotnej Uniwersytetu Medycznego im. Karola Marcinkowskiego w Poznaniu, pod kierunkiem dr inż. Iwony Nowakowskiej.

Artykuł przyjęty do redakcji: 21.10.2016

Artykuł przyjęty do publikacji: 25.11.2016

Źródło finansowania: Praca nie jest finansowana z żadnego źródła. Konflikt interesów: Autorzy deklarują brak konfliktu interesów.

\section{Adres do korespondencji:}

Iwona Nowakowska

ul. Mariana Smoluchowskiego 11

60-179 Poznań

tel.: 618612221

e-mail: iwonanowakowska @op.pl

Zakład Organizacji i Zarządzania w Opiece Zdrowotnej

Uniwersytet Medyczny im. Karola Marcinkowskiego w Poznaniu 